\title{
Role of Mesenchymal Stem Cell-Conditioned Medium (MSC-CM) in the Bone Regeneration: A Systematic Review from 2007-2018
}

\author{
Ismail Hadisoebroto Dilogo ${ }^{1,2}$ and Jessica Fiolin ${ }^{1^{*}}$ \\ ${ }^{1}$ Department of Orthopedics and Traumatology, Faculty of Medicine, Cipto Mangunkusumo Hospital, \\ Universitas Indonesia, Jakarta, Indonesia. \\ ${ }^{2}$ Faculty of Medicine, Stem Cell Integrated Medical Service Unit, Cipto Mangunkusumo Hospital, \\ Universitas Indonesia, Jakarta, Indonesia.
}

Authors' contributions

This work was carried out in collaboration between both authors. Author IHD designed the study, performed the statistical analysis, wrote the protocol, and wrote the first draft of the manuscript. Author JF managed the analyses of the study and the literature searches. Both authors read and approved the final manuscript.

Article Information

DOI: 10.9734/ARRB/2019/v31i230045 Editor(s):

(1) Dr. George Perry, Dean and Professor of Biology, University of Texas at San Antonio, USA.

(1) M. C. Arufe, Universidade da Coruña, As Xubias, Spain. (2) Ali Said Durmus, Firat University, Turkey. (3) Wen-Chi, Yang Department of Internal Medicine, E-Da Hospital, Taiwan (4) Radwa Ali Mehanna, Physiology Department, Alexandria University, Egypt. Complete Peer review History: http://www.sdiarticle3.com/review-history/41691

Review Article

Received 03 March 2018

Accepted 23 May 2018

Published 26 March 2019

\section{ABSTRACT}

Background: The therapeutic value of mesenchymal stem cells (MSCs) in tissue engineering and regenerative medicine is attributable in part to paracrine pathways triggered by several secreted factors secreted into culture media. The secreted factor here is known as the conditioned medium $(\mathrm{CM})$ or secretome.

Objectives: This review is aimed to investigate and summarise the in-vitro, pre-clinical in-vivo studies regarding the role of CM-MSC in bone regeneration from 2007 until 2018

Data Sources: A systematic literature search on PubMed, MEDLINE, OVID, Scopus and Cochrane library was carried out by using search terms: Secretome, conditioned medium, mesenchymal stem cell, bone healing, osteogenic, osteogenesis. 
Methods: A total of 611 articles were reviewed. Ten articles were identified as relevant for this systematic literature review.

Results: Three tables of studies were constructed for in vitro studies and in-vivo studies.

Conclusion: All of the included in-vitro studies and in-vivo studies have shown a promoting effect of bone regeneration at various stages. Although there are no clinical studies regarding the use of CMMSC in the human bone regeneration that have been conducted, transplantation of secretome has shown a promising result in the acceleration of bone healing process.

Keywords: Secretome; conditioned medium; bone regeneration; osteogenic; mesenchymal stem cell; tissue engineering; musculoskeletal.

\section{INTRODUCTION}

Bone healing is a multistage repair process that involves complex yet well-orchestrated process which depends on numerous factors including cellular, molecular, and mechanical events. The skeleton differs from other adult tissues that generate scar tissue at the site of an injury; it heals by forming new bone that is indistinguishable from an uninjured bone. However, bone healing remains challenging in musculoskeletal care [1]. Limitations with the use of autograft and allograft have led numerous studies into the exciting and evolving field of mesenchymal stem cells (MSCs) tissue engineering [2].

However, several issues with stem cells remain to be addressed, including tumorigenesis, [3] poor survival of implanted cells [4,5], transmission of infectious disease, and hostversus-graft disease. Besides, stem cell culture procedure is limited by a number of technical and ethical issues such as complicated safety and quality management issues with cell handling with the need of higher capital investment. According to recent literature from 2007-2018, the therapeutic value of mesenchymal stem cells in tissue engineering and regenerative medicine is attributable in part to paracrine pathways $[6,7]$ triggered by several secreted factors secreted into culture media. The secreted factor here is known as the conditioned medium (CM) or secretome.

The secretome of MSCs is special, as a nondonor-specific and can be lyophilised, enabling more practical storage conditions [6]. These findings reinforce many researchers to look further into this molecule regarding their contents in the bone healing capability and to solve the existing problems with cell handling described earlier. This systematic review aims to elaborate studies that have been conducted to evaluate the osteogenic potency or the bone regeneration capability of secretome/CM-MSC.

\section{METHODS}

A systematic literature search using PubMed, Medline, OVID, Scopus and Cochrane library was carried out. The following keywords and search terms were used in the following order in each of the databases using a snowballing technique to cite the relevant articles: Secretome, conditioned medium, mesenchymal stem cells, osteogenic. The search was performed by an initial reviewer and subsequently checked by a second reviewer. Discussion resolved any disputes about whether an article met the inclusion criteria. The following inclusion criteria were applied:

1. Studies/reviews describing the potency of secretome or conditioned-medium mesenchymal stem cells in the acceleration of osteogenesis or chondrogenesis

2. Studies that involve osteogenicity in the maxillofacial surgery

3. Studies involving the acceleration of bone healing in the hypoxic condition

4. Studies published within 10 years prior

5. Studies in the English language

6. In-vitro and in-vivo studies

\subsection{Exclusion Criteria Including}

1. Effect of conditioned-medium MSC in other organs (cardiovascular, genitourinary, peripheral nerve)

2. Unpublished literature

3. Studies that evaluate osteogenic potency in other organs other than bone

4. Studies evaluating $\mathrm{CM}$ in the periodontal tissue

A total of 611 articles were reviewed. 10 articles were identified relevant with the aim of this systematic review. The studies included and excluded have been summarized in Fig. 1. 


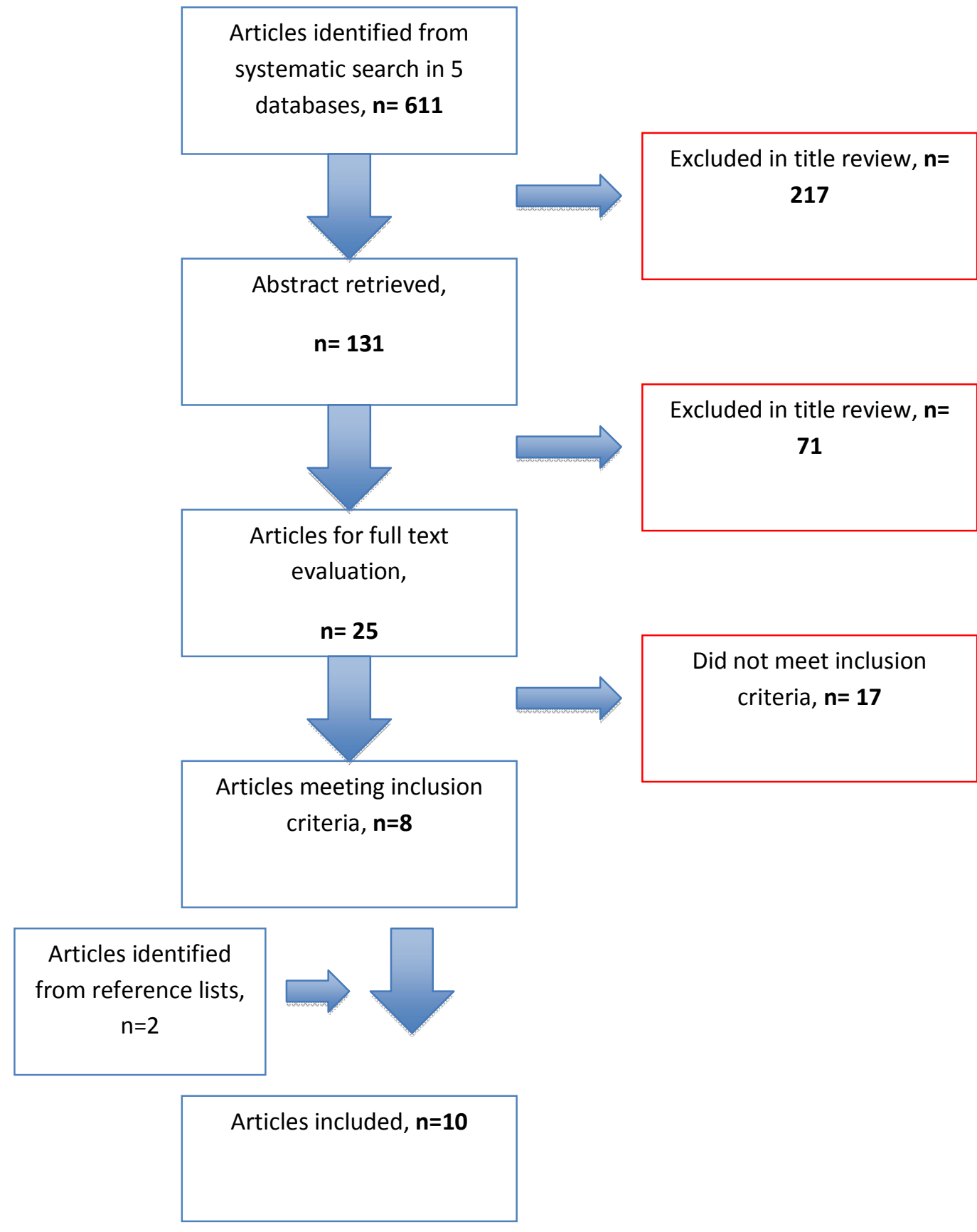

Fig. 1. Included and excluded studies

\section{RESULTS}

The role of CM-MSC in the in-vitro studies is summarised in Table 1 . There was one study evaluating the role of MSC-CM in vitro. In 2014, Lee et al. hypothesised that embroid bodies (EBs) that were composed of either human embryonic stem cells (hESCs) or human induced pluripotent stem cells (hiPSCs) with a hMSC-CM may stimulate mesodermal lineage induction. Through this induction, differentiation toward the osteogenic and chondrogenic lineage proven by quantitative reverse-transcription-polymerase chain reaction (qRT-PCR), cytochemistry, immunocytochemistry, and flow cytometry, was promoted [7]. 
Meanwhile, role of CM-MSC in animal studies is summarised in Table 2. 9 studies were evaluating various pathways of CM-MSC in accelerating the bone regeneration. The most critical factor for fracture union is the blood supply to the fracture site. There were two studies which evaluated the importance of angiogenesis capability hence the vascular endothelial growth factor (VEGF) in CM-MSC during acceleration of bone regeneration. In 2017, Katagiri et al. [8]. examined the value VEGF in the CM-MSC to accelerate the bone healing by comparing four groups of treatment consisting of MSC-CM, MSC-CM + anti-VEGF antibody, phosphate buffer saline (PBS), and control group with an unfilled defect. His research besides has successfully quantified the amount of IGF-1, VEGF, and TGF- $\beta 1$ using ELISA, using a reconstruction computed tomography (CT) evaluation also proven a significant increase of new bone formation in the MSC-CM group compared to other groups which were verified by histological and immunohistochemistry (IHC) analysis. Meanwhile, Wang et al[9] in 2011 investigated the effects of hypoxic MSC-CM on tissue ingrowth, angiogenesis, and bone repair in the diabetic Sprague Dawley (SD) rats and proved that MSC-CM prepared under hypoxic conditions showed positive effects on angiogenesis following subcutaneous implantation and facilitated healing of segmental bone defect in a diabetic rat model.

When normal bone healing process is insufficient, supportive therapeutic strategies can be used to stimulate and augment bone regeneration (Walsh et al., 2008) [10]. Sun et al., 2012 [11] has reported that to enhance the effect of MSC in proliferation and differentiation of osteoblasts, a sensitive microenvironment can be formed. Chang et al. in 2015 proved that CMrMSC collected under hypoxic condition could effectively influence bone regeneration through enhanced migration and adhesion of endogenous MSC in the SD rats with calvaria bone defect [12].

There were four studies including the works of Feng in 2012 [13], Katagiri 2013 [14], Linero 2014 [15], and Brudette 2017 [6], which evaluated the efficacy of CM-MSC from many sources (murine, human, human, human and amnion respectively) in rats' (except for Linero in rabbit) calvaria and mandible. All studies were evaluated using conventional radiograph, reconstruction CT scan, histological analysis,
IHC, western blot, and RT-PCR. All studies have shown positive results where secretome enhanced the proliferation and migration of MSC osteogenic differentiation significantly.

A novel route of CM-MSC administration had been introduced by Ando et al in 2014 [16] who administered serum-free CM-hMSC locally in high-speed distraction osteogenesis (DO) in a mouse model. The CM-MSC was proved to promoted the recruitment of murine CMSCs and of endothelial cells/endothelial progenitor cells (EC/EPCs), and the establishment of a neoangiogenic network hence accelerating neo callus formation in the DO gap.

Implant fixation is commonly used in nonunion or bone defect cases, and its integration with $\mathrm{CM}$ MSC should be understood. One of the material commonly used is titanium (Ti). In 2013, Tsuchiya investigated methods to enhance the stability of $\mathrm{Ti}$ implants using CM-BMSCs. Rat BMSC-CM was successfully immobilised on $\mathrm{Ti}$ implants [17]. The immobilised CM contained about 2000 proteins, including collagen type I, bone sialoprotein, fibronectin, and VEGF, which are essential for new bone formation. CM promoted cell adhesion and osteocalcin gene expression of rat BMSCs. The labeled CM remained associated with the $\mathrm{Ti}$ implant at 1,7 , 14 , and 28 days postimplantation. Compared to controls, the removal torque value and $\mathrm{BIC}$ of $\mathrm{Ti}$ implants with immobilised CM were higher than on days 1,7 , and 14 after implantation.

\section{DISCUSSIONS}

It is clear that the included studies have demonstrated that the therapeutic effects of transplanted stem cells are considered to be effective for tissue regeneration. In addition, they play an essential role as cellular modulators, apart from their multi-potent differentiation ability [18-20]. Stem cells, including MSCs, are attracted to damaged tissue site where they produce the secretome that enhances angiogenesis, reduces inflammation, promotes tissue repair, and inhibits fibrosis and cell apoptosis [21-23]. The application of cell-free secretome may avoid the limitations associated with cell therapy, including higher costs for cell preparation, longer waiting time, and immune incompatibility $[24,25]$. Although it has been proven that the effect of MSC is mainly due to its paracrine effect, reviews regarding the osteogenic potency of this paracrine effect concerning bone regeneration promotion are scarce. 
Table 1. In-vitro studies of secretome MSC role in bone regeneration

\begin{tabular}{|c|c|c|c|c|}
\hline Study & Secretome source & Method & Evaluation & Results \\
\hline $\begin{array}{l}\text { Lee, } 2014 \\
\text { Tissue eng part } A^{7}\end{array}$ & hMSC & $\begin{array}{l}\text { Hypothesis: treatment of } \\
\text { embryoid bodies (EBs) } \\
\text { composed of either human } \\
\text { embryonic stem cells } \\
\text { (hESCs) or human induced } \\
\text { pluripotent stem cells } \\
\text { (hiPSCs) with a hMSC- } \\
\text { conditioned medium (CM) } \\
\text { may stimulate mesodermal } \\
\text { lineage induction and } \\
\text { subsequent differentiation } \\
\text { toward the osteogenic and } \\
\text { chondrogenic lineage. } \\
\text { Group I: EB culture + hMSC- } \\
\text { CM (each cultured in } \\
\text { osteogenic \& chondrogenic } \\
\text { medium) } \\
\text { Group II: EB culture + EB } \\
\text { medium (each cultured in } \\
\text { osteogenic \& chondrogenic } \\
\text { medium) }\end{array}$ & $\begin{array}{l}\text { Quantitative RT-PCR for } \\
\text { osteogenic (ALP, COL I, OP, } \\
\text { ON, OC genes) \& } \\
\text { chondrogenic (COL II, AGG } \\
\text { genes) } \\
\text { Chemical staining with } \\
\text { osteogenic (Alizarin red S \& } \\
\text { von Kossa) and chondrogenic } \\
\text { (Alcian Blue \& Safranin O } \\
\text { staining) then evaluated using } \\
\text { a light microscope. } \\
\text { IHC osteogenic (human OC } \\
\text { antibody) and chondrogenic } \\
\text { (anti-human COL II antibody) } \\
\text { Flowcytometry analysis for } \\
\text { osteogenic with rhodamine- } \\
\text { conjugated OC antibody then } \\
\text { analysis by FACS Aria I using } \\
\text { CellQuest software }\end{array}$ & $\begin{array}{l}\text { qRT-PCR: expressions of osteogenic } \\
\text { marker genes were significantly enhanced } \\
\text { in the hMSC-CM treatment group compared } \\
\text { with the untreated control group. OL II and } \\
\text { AGG expressions were significantly } \\
\text { enhanced in the hMSC-CM treatment group } \\
\text { compared with the untreated control group. } \\
\text { Calcium deposition was enhanced in } \\
\text { hMSC-CM hESCs compared with untreated } \\
\text { hESCs. hMSC-CM hESCs were more } \\
\text { positively stained with Alcian Blue and } \\
\text { Safranin O staining compared with } \\
\text { untreated hESCs } \\
\text { IHC: hMSC-CM-treated hESCs showed } \\
\text { more positive signals for OC (red) and COL } \\
\text { II (green) compared with the untreated } \\
\text { hESCs } \\
\text { Flow cytometric: } 21.3 \% \text { of the hMSC-CM } \\
\text { hESCs cultured in the osteogenic medium } \\
\text { were OC positive, whereas only } 14.8 \% \text { of } \\
\text { the untreated hESCs were positive } \\
\text { Conclusion: enhanced osteogenic and } \\
\text { chondrogenic differentiation compared with } \\
\text { untreated EBs, as evaluated using qRT- } \\
\text { PCR, cytochemistry, immunocytochemistry, } \\
\text { and flow cytometry }\end{array}$ \\
\hline
\end{tabular}


Table 2. In-vivo animal studies of secretome MSC role in bone regeneration

\begin{tabular}{|c|c|c|c|c|}
\hline Study & Secretome source & Trial & Evaluation & Results \\
\hline $\begin{array}{l}\text { Wang, } 2011 \\
\text { J Tissue Eng } \\
\text { Med9 }\end{array}$ & hMSC & $\begin{array}{l}\text { The hypothesis investigates the effects of } \\
\text { MSC-CM on tissue ingrowth, angiogenesis and } \\
\text { bone repair in diabetes mellitus (DM) SD rats. } \\
\text { Group 1(subcutaneous model): } \\
\text { - normal control } \\
\text { - DM control } \\
\text { - DM MSC-CM } \\
\text { - DM 293-CM } \\
\text { - DM MEM } \\
\text { Group II (bone defect model): } \\
\text { - normal control } \\
\text { - DM control } \\
\text { - DM MSC-CM } \\
\text { - DM 293-CM } \\
\text { - DM MEM }\end{array}$ & $\begin{array}{l}\text { - Xray at 3,5, } 8 \text { wk } \\
\text { - Histology exam at } 3 \text {, } \\
8 \text { wk: CD } 31 \text { stain for } \\
\text { endothelial cell count } \\
\text { - Micro CT at } 8 \text { wk: } \\
\text { measure BMD and } \\
\text { bone volume }\end{array}$ & $\begin{array}{l}\text { MSC-CM addition by subcutaneous } \\
\text { implantation could facilitate healing of } \\
\text { segmental bone defects in a diabetic } \\
\text { rat model by positive effects on } \\
\text { angiogenesis mechanism }\end{array}$ \\
\hline \multirow[t]{2}{*}{$\begin{array}{l}\text { Katagiri, } 2017^{8} \\
\text { Maxillofacial } \\
\text { Plastic and } \\
\text { Recon Surg }\end{array}$} & hMSCs & $\begin{array}{l}\text { Hypothesis: angiogenesis is an important step } \\
\text { for bone regeneration, and VEGF is one of the } \\
\text { crucial factors in MSC-CM that would enhance } \\
\text { its osteogenic potential }\end{array}$ & $\begin{array}{l}\text { Human IGF-1, VEGF, } \\
\text { TGF- } \beta \text { identification } \\
\text { by ELISA }\end{array}$ & $\begin{array}{l}\text { In MSC-CM, the concentrations of IGF- } \\
1, \text { VEGF, and TGF- } \beta 1 \text { were } 1515.6 \pm \\
211.8 \mathrm{pg} / \mathrm{mL}, 465.8 \pm 108.8 \mathrm{pg} / \mathrm{mL} \text {, } \\
\text { and } 339.8 \pm 14.4 \mathrm{pg} / \mathrm{mL} \text {, }\end{array}$ \\
\hline & & $\begin{array}{l}24 \text { Wistar/ST rats with } 5 \mathrm{~mm} \text { diameter calvaria } \\
\text { bone defect } \\
\text { Group I: MSC-CM } \\
\text { Group II: MSC-CM + anti-VEGF antibody } \\
\text { Group III: PBS } \\
\text { Group IV: unfilled defect }\end{array}$ & $\begin{array}{l}\text { 3D-CT evaluation } \\
\text { IHC analysis by } \\
\text { CD31-, CD105-, or } \\
\text { FLK-1 }\end{array}$ & $\begin{array}{l}\text { Newly formed bone area in the MSC- } \\
\text { CM group }(72.3 \pm 17.1 \%) \text { increased } \\
\text { significantly compared to those in the } \\
\text { Defect }(22.2 \pm 8.0 \%), \text { PBS }(30.9 \pm \\
6.2 \%) \text {, and MSC-CM + anti-VEGF } \\
(33.1 \pm 12.4 \%) \text { groups ( }<<0.05) \text {. No } \\
\text { statistically significant differences } \\
\text { between the MSC-CM + anti-VEGF } \\
\text { group and other controls were found. }\end{array}$ \\
\hline
\end{tabular}




\begin{tabular}{|c|c|c|c|c|}
\hline Study & Secretome source & Trial & Evaluation & Results \\
\hline & & & & $\begin{array}{l}\text { Histological analysis also showed well- } \\
\text { regenerated bone in the MSC-CM } \\
\text { group compared with the other groups. }\end{array}$ \\
\hline & & & & $\begin{array}{l}\text { IHC staining showed that numerous } \\
\text { CD31-, CD105-, or FLK-1-positive cells } \\
\text { were present throughout the specimen } \\
\text { in the MSC-CM group. In MSC-CM + } \\
\text { anti-VEGF, PBS, and Defect groups, } \\
\text { fewer CD31-, CD105-, or FLK-1- } \\
\text { positive cells were seen }\end{array}$ \\
\hline & & & & $\begin{array}{l}\text { MSC-CM addition could enhance bone } \\
\text { regeneration compared to MSC-CM + } \\
\text { anti VEGF, PBS and unfilled defect } \\
\text { hence showing the possibility that } \\
\text { MSC-CM bone healing acceleration is } \\
\text { via the effect of VEGF. }\end{array}$ \\
\hline \multirow[t]{4}{*}{$\begin{array}{l}\text { Chang, } 2015^{12} \\
\text { Mol Cells }\end{array}$} & \multirow[t]{4}{*}{ rMSC } & $\begin{array}{l}\text { Hypothesis: conditioned medium collected } \\
\text { under hypoxic condition could effectively } \\
\text { influence bone regeneration through enhanced } \\
\text { migration and adhesion of endogenous MSC. }\end{array}$ & $\begin{array}{l}\text { Defect evaluation: 3D } \\
\text { reconstruction CT } \\
\text { Staining with calcein, } \\
\text { fluorescent images by } \\
\text { confocal microscope }\end{array}$ & $\begin{array}{l}\text { After } 24 \mathrm{~h} \text {, the migration rate of rMSC- } \\
\mathrm{HCM} \text { was } 30-\text { and } 4.3-\text { fold higher than } \\
\text { that of rMSC-SFM and rMSC-NCM, } \\
\text { respectively }\left({ }^{*} p<0.05 \text { vs. SFM and }\right. \\
\text { NCM) }\end{array}$ \\
\hline & & 21 SD rats with calvarial bone defect model & & \\
\hline & & $\begin{array}{l}\text { Group 1: } 1 \mathrm{ml} \mathrm{SFM} \mathrm{(serum-free} \mathrm{medium)} \mathrm{+} \\
\text { greenplast } \\
\text { Group II: } 1 \mathrm{ml} \mathrm{NCM} \mathrm{(normoxic} \mathrm{conditioned} \\
\text { medium) + greenplast }\end{array}$ & & $\begin{array}{l}\text { The spreadability of HCM-treated } \\
\text { rMSCs was } 75 \% \text { greater than that of } \\
\text { SFM-treated rMSCs and } 25 \% \text { greater } \\
\text { than that of NCM- treated rMSCs. }\end{array}$ \\
\hline & & $\begin{array}{l}\text { Group III: } 1 \text { ml HCM (Hypoxic conditioned } \\
\text { medium) + greenplast }\end{array}$ & & $\begin{array}{l}\text { Percentage of new bone formation in } \\
\text { NCM and HCM significantly higher } \\
\text { than in SFM from } 28-56 \text { days after } \\
\text { treatment }\end{array}$ \\
\hline
\end{tabular}




\begin{tabular}{|c|c|c|c|c|}
\hline \multirow[t]{3}{*}{ Study } & Secretome source & Trial & Evaluation & Results \\
\hline & & & & $\begin{array}{l}\text { Calcein density in HCM group was 5.6- } \\
\text { and } 2.3 \text { - fold higher than in SFM and } \\
\text { NCM groups ( }<<0.05 \text { vs. SFM and } \\
\text { NCM) }\end{array}$ \\
\hline & & & & $\begin{array}{l}\text { Under hypoxic conditions, behavioral } \\
\text { changes of endogenous MSC through } \\
\text { microRNA221 targeted- ICAM-1 } \\
\text { expression may be a potential } \\
\text { treatment for those with bone defects. }\end{array}$ \\
\hline \multirow[t]{2}{*}{$\begin{array}{l}\text { Feng Li, } 2012^{13} \\
\text { Biochem and } \\
\text { Biophys Res }\end{array}$} & \multirow[t]{2}{*}{ Murine BMSC } & $\begin{array}{l}\text { Aim: to investigate whether factors secreted by } \\
\text { MSCs undergoing osteogenic differentiation } \\
\text { induce expression of osteoblast markers in } \\
\text { exogenous MSCs as well as their migration }\end{array}$ & $\begin{array}{l}\text { ALP assay every day } \\
7\end{array}$ & $\begin{array}{l}\text { ALP activity was elicited by the CM at } \\
\text { day } 15 \text { and } 20 \text { following osteogenic } \\
\text { differentiation }\end{array}$ \\
\hline & & $\begin{array}{l}\text { exogenous MSCs as well as their migration } \\
\text { One million MSCs were cultured in osteogenic } \\
\text { medium and the medium conditioned by the } \\
\text { cells was collected at day } 0,5,10,15 \text { and } 20 \text {. } \\
\text { Prepare medium supplemented with } \\
\text { neutralizing antibodies, BMP-2 (R\&D, } \\
\text { Minneapolis, MN) and VEGF (Santa Cruz, } \\
\text { Santa Cruz, CA) neutralizing antibodies were } \\
\text { added in the conditioned medium at a } \\
\text { concentration of } 2.5 \text { ug/ ml and } 5 \text { ug/ml, } \\
\text { respectively. The media were then used for } \\
\text { assessing activities of these factors. } \\
\text { A tunnel was created within five mice femurs } \\
\text { cavities via the femoral condyle using a } 26 \\
\text { gauge needle. Subsequently,a smaller gauge } \\
\text { needle ( } 30 \text { gauge) attached to a syringe }\end{array}$ & $\begin{array}{l}\text { Western Blot to } \\
\text { evaluate protein anti- } \\
\text { mouse VEGF, PEDF, } \\
\text { Col1, GAPDH, goat } \\
\text { anti-BMP2 (R\&D, } \\
\text { Minneapolis, MN), } \\
\text { rabbit anti-osteocalcin } \\
\text { (Millipore Corp, } \\
\text { Billerica, MA) followed } \\
\text { by HRP-conjugated } \\
\text { secondary antibodies. } \\
\text { The cells retrieved } \\
\text { from marrow and } \\
\text { bone of the recipient } \\
\text { mice at four } \\
\text { consecutive weeks } \\
\text { were expanded in } \\
\text { culture in the }\end{array}$ & $\begin{array}{l}\text { The BMP-2 synthesis was maximal } \\
\text { beginning at day } 5 \text { and continued up to } \\
\text { day } 15 \text { and then began to show a } \\
\text { decline. VEGF appeared to be } \\
\text { synthesized throughout the } \\
\text { differentiation period with a slight } \\
\text { increase at day } 10 \text {. PEDF synthesis } \\
\text { appeared maximal at day } 10 \text { and } \\
\text { showed a steady decline to day } 25 \text {. } \\
\text { BMP-2 expression was detected } \\
\text { beginning at day } 3 \text { in bone marrow } \\
\text { (BM) following cell infusion into femurs. } \\
\text { There was no expression of BMP-2 by } \\
\text { donor cells in bone (B) at all the time } \\
\text { periods assessed. VEGF was } \\
\text { expressed by donor cells in bone } \\
\text { marrow beginning at day } 1 \text { through day } \\
\text { 14. Expression of VEGF by donor cells }\end{array}$ \\
\hline
\end{tabular}




\begin{tabular}{|c|c|c|c|c|}
\hline Study & Secretome source & Trial & Evaluation & Results \\
\hline & & $\begin{array}{l}\text { containing cells for injection was inserted. } \\
\text { MSCs for injection were suspended in } 20 \text { II of } \\
\text { PBS ( } 210^{6} \text { cells) and delivered within the } \\
\text { bone cavity by slowly retracting the needle } \\
\text { while depositing cells. Donor GFP+ cells were } \\
\text { retrieved from recipient femur bones and } \\
\text { marrow at } 1,3,7,14 \text { and } 28 \text { days following cell } \\
\text { infusion. Retrieved cells were expanded in } \\
\text { culture in a medium supplemented with Zeocin } \\
\text { for selection of GFP+ donor cells. }\end{array}$ & $\begin{array}{l}\text { presence of Zeocin for } \\
\text { seven days. The } \\
\text { expanded cells were } \\
\text { sorted by FACS for } \\
\text { the GFP+ donor cells } \\
\text { prior to their use for } \\
\text { gene expression } \\
\text { analysis. } \\
\text { RNA isolation and RT- } \\
\text { PCR to detect BMP-2, } \\
\text { VEGF, SDF-1 genes }\end{array}$ & $\begin{array}{l}\text { in bone appeared to increase for an } \\
\text { extended period. SDF-1 was equally } \\
\text { expressed at all time periods by donor } \\
\text { cells in bone marrow and bone. MSCs } \\
\text { marked with GFP and Zeocin resistant } \\
\text { genes were infused into femurs and } \\
\text { retrieved from bone marrow and bone } \\
\text { at specified days. }\end{array}$ \\
\hline \multirow[t]{4}{*}{$\begin{array}{l}\text { Katagiri, } 2013^{14} \\
\text { Int J Oral } \\
\text { Maxillofac } \\
\text { Implants }\end{array}$} & \multirow[t]{4}{*}{ hMSCs } & $\begin{array}{l}\text { Aim: to investigate the effects of hBM-MSC- } \\
\mathrm{CM} \text { on bone regeneration and its ability to } \\
\text { induce endogeneous stem cell mobilization } \\
\text { and bone regeneration }\end{array}$ & $\begin{array}{l}\text { Cellular migration by } \\
\text { HE staining and light } \\
\text { microscope cell count }\end{array}$ & $\begin{array}{l}\text { MSC-CM increased rMSC migration } \\
\text { more than seven-fold compared to } \\
\text { DMEM(-) }\end{array}$ \\
\hline & & $\begin{array}{l}24 \text { Wistar/ST rats with } 2 \text { circular full-thickness } \\
\text { bone defects ( } 5 \mathrm{~mm} \text { diameter) } \\
\text { Group I: MSC-CM } \\
\text { Group II: PBS } \\
\text { Group III: unfilled defect }\end{array}$ & $\begin{array}{l}\text { RT-PCR analysis of } \\
\text { ALP, type I alpha } 2 \\
\text { collagen, OCN, } \\
\text { Runx2, GAPDH }\end{array}$ & $\begin{array}{l}\text { The ALP, OCN, and Runx } 2 \text { genes } \\
\text { expression levels were significantly } \\
\text { upregulated in rMSCs cultured in } \\
\text { MSC-CM compared to rMSCs cultured } \\
\text { in control medium }\end{array}$ \\
\hline & & $\begin{array}{l}\text { Rats were sacrificed at } 2 \text { or } 4 \text { wk after } \\
\text { transplantation ( } n=4 \text { per group) }\end{array}$ & $\begin{array}{l}\text { Micro -CT analysis, } \\
\text { analyzed using OsiriX } \\
\text { imaging software }\end{array}$ & $\begin{array}{l}\text { After two weeks, the mean area of } \\
\text { newly regenerated bone in the MSC- } \\
\text { CM defects was significantly increased }\end{array}$ \\
\hline & & & $\begin{array}{l}\text { Histological analysis } \\
\text { using HE stain and } \\
\text { light microscope }\end{array}$ & $\begin{array}{l}\text { compared to that of the unfilled defects } \\
\text { and the PBS-treated sites }(81.50 \% \pm \\
2.7 \%, 8.63 \% \pm 1.78 \% \text {, and } 60.63 \% \pm \\
5.8 \% \text {, respectively). After four weeks, } \\
\text { the defect areas were almost } \\
\text { completely filled by newly formed bone } \\
\text { in the MSC-CM and PBS groups } \\
(93.07 \% \pm 6.6 \% \text { and } 84.04 \% \pm 4.9 \% \text {, } \\
\text { respectively). }\end{array}$ \\
\hline
\end{tabular}




\begin{tabular}{|c|c|c|c|c|}
\hline Study & Secretome source & Trial & Evaluation & Results \\
\hline & & & & $\begin{array}{l}\text { At } 2 \text { weeks, the bone defect in the } \\
\text { MSC-CM group was almost covered } \\
\text { with newly regenerated bone. Whereas } \\
\text { in the PBS group, the defect was } \\
\text { covered with a large amount of } \\
\text { connective tissue. } \\
\text { At } 4 \text { weeks, newly regenerated bone } \\
\text { was partially noticeable within the } \\
\text { defect of the PBS group. However, in } \\
\text { the MSC-CM group, the defect was } \\
\text { almost completely replaced by mature } \\
\text { bone tissue }\end{array}$ \\
\hline $\begin{array}{l}\text { Linero, } 2014^{15} \\
\text { PLoS ONE }\end{array}$ & hAdMSC & $\begin{array}{l}\text { Aim: to evaluate the ability of hAd-MSC and } \\
\text { their CM by radiographic, morphometric and } \\
\text { histological analysis, and to repair surgical } \\
\text { bone lesions using an in vivo model (rabbit } \\
\text { mandibles) delivered with human blood plasma } \\
\text { hydrogels (HBPH) } \\
\text { Group I: } 12 \text { rabbits with HBPHs + Ad-MSC + } \\
\text { HBPHs w/o cells on contralateral side (control) } \\
\text { Each } 4 \text { animal sacrificed at } 15,30,45 \text { days } \\
\text { after surgery } \\
\text { Group II: } 4 \text { rabbits with HBPHs + Ad-MSC both } \\
\text { sides and sacrificed } 3,6,9,12 \text { days after } \\
\text { treatment } \\
\text { Group III: } 3 \text { rabbits with a hydrogel containing } \\
\text { CM-1 on one side and CM-2 on contralateral } \\
\text { side; sacrificed } 45 \text { days after surgery. }\end{array}$ & $\begin{array}{l}\text { Radiograph analysis } \\
\text { by Image J } \\
\text { Histological analysis } \\
\text { Immunohistochemistry } \\
\text { analysis }\end{array}$ & $\begin{array}{l}\text { Ad-MSC enhances bone regeneration } \\
\text { process more through paracrine } \\
\text { mechanism (conditioned medium). } \\
\text { When paracrine factors collected and } \\
\text { applied as CM are used instead of Ad- } \\
\text { MSC itself which is undetected after } 12 \\
\text { days of implantation, the amount and } \\
\text { quality of regenerated bone is similar. }\end{array}$ \\
\hline $\begin{array}{l}\text { Burdette, } 2017^{6} \\
\text { J Craniofac } \\
\text { Surg }\end{array}$ & $\begin{array}{l}\text { Amnion-derived } \\
\text { secretome }\end{array}$ & $\begin{array}{l}\text { Aim: Evaluate the efficacy of this secretome } \\
\text { biotherapeutic in vitro on the proliferation and } \\
\text { migration of MSC and osteoprogenitor cells as }\end{array}$ & $\begin{array}{l}\text { Micro CT and } \\
\text { histology evaluation }\end{array}$ & $\begin{array}{l}\text { The secretome biotherapeutic } \\
\text { enhanced the proliferation and } \\
\text { migration of MSC and proliferation of }\end{array}$ \\
\hline
\end{tabular}




\begin{tabular}{|c|c|c|c|c|}
\hline Study & Secretome source & Trial & Evaluation & Results \\
\hline & & $\begin{array}{l}\text { well as in vivo using a critical size rat calvarial } \\
\text { defect model. } \\
\text { Ten male Fischer } 344 \text { (CDF) rats with } 8 \mathrm{~mm} \\
\text { diameter calvarial defect } \\
\text { Group I: saline + collagen scaffold } \\
\text { Group II: secretome + collagen scaffold } \\
\text { Sacrificed at four weeks or } 12 \text { weeks }\end{array}$ & & $\begin{array}{l}\text { osteoprogenitor cells. The secretome } \\
\text { improved new bone volume and } \\
\text { connectivity by } 12 \text { weeks and } \\
\text { significantly improved angiogenesis at } \\
\text { four weeks and bone density at } 4 \text { and } \\
12 \text { weeks with no deleterious effects. } \\
\text { The improvement in new bone volume, } \\
\text { connectivity, and angiogenesis } \\
\text { suggests that the secretome } \\
\text { biotherapeutic has beneficial effects on } \\
\text { bone healing, and a higher dose of the } \\
\text { secretome biotherapeutic may further } \\
\text { improve bone regeneration. }\end{array}$ \\
\hline $\begin{array}{l}\text { Ando, } 2014^{16} \\
\text { Bone }\end{array}$ & hBM-MSC-CM & $\begin{array}{l}\text { Hypothesis: local administration of serum-free } \\
\text { conditioned medium from human } \\
\text { mesenchymal stem cells (MSC-CM) } \\
\text { accelerated callus formation in the mouse H- } \\
\text { DO model } \\
\text { female ICR mice DO model } \\
\text { Control group: performed distraction after three } \\
\text { days latency period and continued for eight } \\
\text { days at } 0.2 \mathrm{~mm} / 12 \mathrm{~h} \text { which was sacrificed at } \\
15 \text { days after surgery } \\
\text { MSC Treatment group: } 3 \times 10^{5} \text { MSCs or FBs } \\
\text { transplanted with distraction rate of } 0.4 \text { mm/ } 12 \\
\text { h, length of increase } 3.2 \text { mm in } 4 \text { days which } \\
\text { was sacrificed } 5,7 \text {, or } 11 \text { days after surgery } \\
\text { MSC-CM group: } 20 \mu \text { l serum-free DMEM } \\
\text { (control) or FB-CM or MSC-CM injected }\end{array}$ & $\begin{array}{l}\text { Histology analysis } \\
\text { using HE stain } \\
\text { Histomorphometric } \\
\text { analysis } \\
\text { IHC analysis } \\
\text { cytokine antibody } \\
\text { assay } \\
\text { Osteoblast } \\
\text { differentiation using } \\
\text { ALP assay }\end{array}$ & $\begin{array}{l}\text { The secretomic analysis identified } \\
\text { factors contained in MSC-CM that } \\
\text { recruit murine bone marrow stromal } \\
\text { cells (mBMSCs) and endothelial } \\
\text { cells/endothelial progenitor cells } \\
\text { (EC/EPCs), inhibit inflammation and } \\
\text { apoptosis, and promote osteoblast } \\
\text { differentiation, angiogenesis, and cell } \\
\text { proliferation. Functional assays } \\
\text { identified MCP-1/-3 and IL-3/-6 as } \\
\text { essential factors in recruiting mBMSCs } \\
\text { and EC/EPCs. Moreover, IL-3/-6 } \\
\text { enhanced the osteogenic } \\
\text { differentiation of mBMSCs. MSC-CM } \\
\text { that had been depleted of MCP-1/-3 } \\
\text { failed to recruit mBMSCs, and } \\
\text { consequently failed to promote callus } \\
\text { formation. }\end{array}$ \\
\hline
\end{tabular}


Dilogo and Fiolin; ARRB, 31(2): 1-16, 2019; Article no.ARRB.41691

\begin{tabular}{|c|c|c|c|c|}
\hline Study & Secretome source & Trial & Evaluation & Results \\
\hline & & $\begin{array}{l}\text { transcutaneously into the center of distraction } \\
\text { zone using a } 29 \text {-gauge needle on days } 3,5 \text {, } \\
\text { and } 7 \text {; mice were sacrificed at } 7 \text { and } 11 \text { days } \\
\text { after surgery. }\end{array}$ & & \\
\hline \multirow{6}{*}{$\begin{array}{l}\text { Tsuchiya, } \\
2013^{17} \\
\text { Int J Oral } \\
\text { Maxillofac } \\
\text { Implants }\end{array}$} & \multirow[t]{6}{*}{$\begin{array}{l}\text { BMSC from rat } \\
\text { femur }\end{array}$} & $\begin{array}{l}\text { Purpose: To improve the stability of titanium } \\
\text { (Ti) implants using the conditioned medium } \\
\text { (CM) derived from rat bone marrow stromal } \\
\text { cell (BMSC). }\end{array}$ & $\begin{array}{l}\text { Ti implants topology } \\
\text { observed by SEM } \\
\text { microscopy }\end{array}$ & $\begin{array}{l}\text { Immobilized CM contained about } 2000 \\
\text { proteins (collagen type I, bone } \\
\text { sialoprotein, fibronectin, and VEGF) }\end{array}$ \\
\hline & & $\begin{array}{l}\text { Rat BMSC-CM was immobilized on the surface } \\
\text { of Ti implants with calcifying solution }\end{array}$ & $\begin{array}{l}\text { Ti-immobilized CM } \\
\text { analyzed by liquid } \\
\text { chromatography with } \\
\text { tandem mass }\end{array}$ & $\begin{array}{l}\text { CM promoted cell adhesion and } \\
\text { osteocalcin gene expression of rat } \\
\text { BMSCs. }\end{array}$ \\
\hline & & & & $\begin{array}{l}\text { Compared to controls, removal torque } \\
\text { value and } \mathrm{BIC} \text { of } \mathrm{Ti} \text { implants with }\end{array}$ \\
\hline & & & $\begin{array}{l}\text { Adhesiveness \& } \\
\text { osteogenic } \\
\text { differentiation: rt-PCR }\end{array}$ & $\begin{array}{l}\text { immobilized CM were higher on days } \\
1,7 \text {, and } 14 \text { post-implantation. }\end{array}$ \\
\hline & & & $\begin{array}{l}\text { Localization of } \mathrm{CM} \text { by } \\
\text { in vivo imaging at day } \\
1,7,14 \text { after implant }\end{array}$ & $\begin{array}{l}\text { During an initial stage, immobilized } \mathrm{CM} \\
\text { components on the surface of } \mathrm{Ti} \\
\text { implants promoted integration into } \\
\text { bone. }\end{array}$ \\
\hline & & & $\begin{array}{l}\text { Removal torque test } \\
\text { and histologic bone- } \\
\text { implant contact (BIC) }\end{array}$ & \\
\hline
\end{tabular}


We have observed that all included studies in this review revealed that the CM-MSC significantly enhances the bone regeneration compared to normal medium $[6,7,9,12-17]$. The secretome was proven to be superior compared to MSC alone [14]. The transplanted MSC have poor differentiation and survival of engrafted stem cells suggesting that the regenerative properties of these cells are exerted primarily through paracrine mechanisms. However, there was a study stating that no superiority between CM-MSC and MSC in terms of osteogenic potency was found [15]. Ad-MSC improves bone regeneration process, and that the amount and quality of regenerated bone is similar when paracrine factors collected and applied as CM are used instead of Ad-MSC [15].

The CM-MSC effect was also proven to be increased under stress condition, including hypoxia $[9,13]$. MSCs express significantly higher levels of several arteriogenic cytokines when subjected to hypoxic stress [26]. When they are deprived of serum, starvation stress induces them to secrete angiogenic factors [27]. In general, severe stress causes cells to activate survival pathways and secrete factors to counteract toxic conditions. 27 Therefore, severe stress conditions may significantly increase the therapeutic efficiency of factors harvested in the MSC-CM.

The most critical factor for new bone formation is adequate blood supply [28]; impairment of angiogenesis at the fracture site usually results in non-union or delayed union [29]. MSCs also have been shown to secrete cytokines and growth factors that can inhibit hypoxia-induced endothelial apoptosis and promote angiogenesis [30]. Several studies have determined that CMMSC, especially that prepared under hypoxic conditions, contains a higher amount of angiogenic factors [30,31]. Wang et al., [25] have proved that MSC-CM has shown significantly higher levels of angiogenesis factors (VEGF and IL-6) and that MSC-CM delivered in gelatin sponges stimulates angiogenesis and promotes fracture healing in a diabetic rat model and may be an alternative strategy for treating fracture non-union in patients with diabetes.

There was one study by Ando et al., advocating a novel administration technique of MSC-CM in a DO model. The study demonstrated that when locally administered into the H-DO gap, MSC-CM promoted new bone callus formation at the distal end of the gap by accelerating the recruitment of endogenous mBMSCs and EC/EPCs. He also elaborated the ten tissue-regenerating trophic factors that participated in the recruitment of endogenous BMSCs and EC/EPCs as well as in osteoblast differentiation, angiogenesis, cell proliferation, and inflammation suppression. This finding offers an opportunity for newer less invasive and effective method of bone healing treatment with MSC-CM.

Mechanical stabilisation is the key factor in the diamond concept of bone healing accompanied with osteoprogenitor cells, osteoinductive proteins, and osteoconductive scaffolds.[32,33] Upon the usage in patients in clinical settings, a combination of MSC-CM with fixation is crucial. There was one study by Tsuchiya that proved that immobilised CM components on the surface of $\mathrm{Ti}$ implants promoted integration into bone during an early stage [17].

Secretome-based approaches using CM may present osteogenic potential advantages over living cells regarding manufacturing, storage, handling, product shelf life and their potential as a ready-to-go biological therapeutic agent [34-41].

Although the use of $\mathrm{CM}$ is generally safe from ethical issues, inflammatory risk, tumorigenesis complication, and even host-versus-graft disease, studies that evaluate the risk, harm, safety of $\mathrm{CM}$ application should be performed, and comparison potency of MSC-CM and MSC are needed [42-50].

Our review also found the diverse source of MSC-CM used from murine, human, human adipose, human bone marrow, and amnion. However, there has been no study comparing the osteogenic potency of each of them. Further research might also evaluate the comparison of dosages related effect in the MSC-CM application to obtain the optimum dosage with the least side effects in the clinical setting.

Finally, more extensive trials on animal models with more extended observation period are required to answer these questions above before conduction clinical trials on human subjects.

\section{CONCLUSION}

All of the included in-vitro studies and in-vivo studies from 2007-2018 have shown a promoting effect of bone regeneration at various stages. Although there is no clinical study regarding the 
use of CM-MSC in the human bone regeneration to this date, transplantation of secretome has shown a promising result in the acceleration of bone healing process.

\section{COMPETING INTERESTS}

Authors have declared that no competing interests exist.

\section{REFERENCES}

1. Zhou J, Lin $\mathrm{H}$, Fang $\mathrm{T}$, et al. The repair of large segmental bone defects in the rabbit with vascularized tissue-engineered bone. Biomaterials. 2010;31(6):1171-1179.

2. Crowley C, Wong JM, Fisher DM, Khan WS. A systematic review on preclinical studies on the use of scaffolds for bone repair in skeletal defects. Curr Stem Cell Res \& Ther. 2013;8:243-52.

3. Wislet-Gendebien S, Poulet C, Neirinckx $\mathrm{V}$, et al. In vivo tumorigenesis was observed after injection of in vitro expanded neural crest stem cells isolated from adult bone marrow. PLoS ONE. 2012; 7:e46425.

4. Ide $\mathrm{C}$, Nakai $\mathrm{Y}$, Nakano $\mathrm{N}$, et al. Bone marrow stromal cell transplantation for treatment of sub-acute spinal cord injury in the rat. Brain Res. 2010;1332:32-47.

5. Toma C, Wagner WR, Bowry S, Schwartz A, Villanueva F. Fate of culture-expanded mesenchymal stem cells in the microvasculature: In vivo observa ons of cell kine cs. Circ Res. 2009;104:398-402.

6. Burdette AJ, Guda T, Thompson ME, Banas R, Sheppard FA. Novel secretome biotherapeutic influences regeneration in critical size bone defects. J Craniofac Surg. 2017; 8:1-8.

7. Lee TJ, Jang J, Kang S, Bhang SH, Jeong $\mathrm{GJ}$, Shin $\mathrm{H}$, et al. Mesenchymal stem cellconditioned medium enhances osteogenic and chondrogenic differentiation of human embryonic stem cells and human induced pluripotent stem cells by mesodermal lineage induction. Tissue Engineering Part A. 2014;20(7):1306-13.

8. Katagiri $W$, Kawai $T$, Osugi M, SugimuraWakayama Y, Sakaguchi K, Kojima T, et al. Angiogenesis in newly regenerated bone by secretomes of human mesenchymal stem cells. Maxillofacial Plastic and Reconstructive Surgery. 2017; 39(1):1-8.

9. Wang CY, Yang HB, Hsu HS, Chen LL, Tsai CC, Tsai KS. Mesenchymal stem cell- conditioned medium facilitates angiogenesis and fracture healing in diabetic rats. J Tissue Eng Regen Med. 2011; 7:1-14.

10. Walsh WR, Langdown AJ, Auld JW, Stephens P, Yu Y, Vizesi F, et al. Effect of low in- tensity pulsed ultrasound on healing of an ulna defect filled with a bone graft substitute. J. Biomed Mater Res B Appl Biomater. 2008;86:74-81.

11. Sun J, Zhou H, Deng Y, Zhang Y, Gu P, $\mathrm{Ge} S$, et al. Conditioned medium from bone marrow mesenchymal stem cells transiently retards osteoblast differentiation by downregulating runx2. Cells Tissues Organs. 2012;196;510-22.

12. Chang W, Kim R, Park SI, Jung YJ, Ham $\mathrm{O}$, Lee $\mathrm{J}$, et al. Enhanced healing of rat calvarial bone defects with hypoxic conditioned medium from mesenchymal stem cells through increased endogenous stem cell migration via regulation of ICAM1 targeted-microRNA-221. Mol Cells. 2015; 38(7):643-50.

13. Li F, Whyte N, Niyibizi C. Differentiating multipotent mesenchymal stromal cells generate factors that exert paracrine activities on exogenous MSCs: Implications for paracrine activities in bone regeneration. Biochemical and Biophysical Research Communications. 2012;426: 475-9.

14. Katagiri W, Osugi M, Kawai T, Ueda M. Novel cell-free regeneration of bone using stem cell-derived growth factors. The international of oral \& maxillofacial implants. 2013;28(4):1009-1016.

15. Linero I, Chaparro O. Paracrine effects of mesenchymal stem cells derived from human adipose tissue in bone regeneration. PLoS One. 2014;9(9): e107001.

DOI: 10.1371./journal.pone.0107001

16. Ando $\mathrm{Y}$, Matsubara K, Ishikawa J, Fujio M, Shohara $\mathrm{R}$, Hibi $\mathrm{H}$, et al. Stem cellconditioned medium accelerates distraction osteogenesis through multiple regenerative mechanisms. Bone. 2014;61: 82-90.

17. Tsuchiya S, Hara K, Ikeno M, Okamoto $\mathrm{Y}$, Hibi $H$, Ueda M. Rat bone marrow stromal cell-conditioned medium promotes early osseointegration of titanium implants. Int $\mathrm{J}$ Oral Maxillofac Implants. 2013;28:1360-9. DOI: 10.11607/jomi.2799

18. Phinney DG, Prockop DJ. Concise review: Mesenchymal stem/multipotent stromal 
cells: the state of transdifferentiation and modes of tissue repair-current views. Stem cells. 20017;25:2896-2902.

19. Fox JM, Chamberlain G, Ashton BA, Middleton J. Recent advances into the understanding of mesenchymal stem cell trafficking. Br J Haematol. 2007;137:491502.

20. Tasso R, Fais F, Reverberi D, Tortelli F, Cancedda $R$. The recruitment of two consecutive and different waves of host stem/progenitor cells during the development of tissue-engineered bone in a murine model. Biomaterials. 2010;31: 2121-29.

21. Caplan Al, Dennis JE. Mesenchymal stem cells as trophic mediators. J Cell Biochem. 2006;98:1076-1084.

22. Timmers L, Lim SK, Arslan F, Armstrong JS, Hoefer IE, Doevendans PA, et al. Reduction of myocardial infarct size by human mesenchymal stem cell conditioned medium. Stem Cell Res. 2007;1:129-137.

23. Yamagata $M$, Yamamoto $A$, Kako $E$, Kaneko N, Matsubara K, Sakai K, et al. Human dental pulp-derived stem cells protect against hypoxic-ischemic brain injury in neonatal mice. Stroke. 2013;44: 551-554.

24. Timmers L, Lim SK, Hoefer IE, Arslan F, Lai $R C$, van Oorschot $A A$, et al. Human mesenchymal stem cell-conditioned medium improves cardiac function following myocardial infarction. Stem Cell Res. 2011;6:206-214.

25. Wang KX, Xu LL, Rui YF, Huang S, Lin $\mathrm{SE}$, Xiong $\mathrm{JH}$, et al. The effects of secretion factors from umbilical cord derived mesenchymal stem cells on osteogenic differentiation of mesenchymal stem cells. PLoS One. 2015;10:e0120593.

26. Ohnishi S, Yasuda T, Kitamura S, Nagaya $\mathrm{N}$. Effect of hypoxia on gene expression of bone marrow-derived mesenchymal stem cells and mononuclear cells. Stem Cells. 2007; 25:1166-1177.

27. Lee $\mathrm{SH}$, Lee $\mathrm{YJ}$, Song $\mathrm{CH}$, Ahn YK, Han HJ. Role of FAK phosphorylation in hypoxia-induced hMSCS migration: involvement of VEGF as well as MAPKS and eNOS pathways. Am J Physiol Cell Physiol. 2010;298:C847-56.

28. Zhou J, Lin H, Fang $\mathrm{T}$, et al. The repair of large segmental bone defects in the rabbit with vascularized tissue engineered bone. Biomaterials. 2010;31(6):1171-1179.
29. Zhang ZY, Teoh SH, Chong MS, et al. Neo-vascularization and bone formation mediated by fetal mesenchymal stem cell tissue- engineered bone grafts in criticalsize femo- ral defects. Biomaterials. 2010; 31(4):608-20.

30. Hung SC, Pochampally RR, Chen SC, et al. Angiogenic effects of human multipotent stromal cell conditioned medium activate the pi3k-akt pathway in hypoxic endothelial cells to inhibit apoptosis, increase survival, and stimulate angiogenesis. Stem Cells. 2007;25(9): 2363-2370.

31. Schlueter C, Weber $H$, Meyer B, et al. Angiogenetic signaling through hypoxia: Hmgb1: An angiogenetic switch molecule. Am J Pathol. 2005;166(4):1259-63.

32. Giannoudis PV, Einhorn TA, Marsh D. Fracture healing: The diamond concept. Injury, Int. J. Care Injured. 2007;38S4:S3S6.

33. Maumus $M$, Jorgensen $C$, Noel D. Mesenchymal stem cells in regenerative medicine applied to rheumatic diseases: Role of secretome and exosomes. Biochimie. 2013;95:2229-34.

34. Vizoso FJ, Eiro N, Cid S, Schneider J, Perez-Fernandez R. Mesenchymal Stem Cell Secretome: Toward cell-free therapeutic strategies in regenerative medicine. Int. J. Mol. Sci. 2017;18:1852.

35. Xu J, Wang B, Sun $Y, W u ~ T$, Liu $Y$, et al. Human fetal mesenchymal stem cell secretome enhances bone consolidation in distraction osteogenesis. Stem Cell Research \& Therapy. 2016;7:134.

36. Kim JM, Kim J, Kim YH, Kim KT, Sung HR, Lee TG, et al. Comparative secretome analysis of human bone marrow-derived mesenchymal stem cells during osteogenesis. J Cell Physiol. 2013;228: 216-224.

37. Maxson S, Burg KJL. Conditioned media cause increases in select osteogenic and adipogenic differentiation markers in mesenchymal stem cell cultures. J Tissue Eng Regen Med. 2008;2:147-54.

38. Burdette AJ, Guda T, Thompson ME, Banas R, Sheppard F. A novel secretome biotherapeutic influences regeneration in critical size bone defects. J Craniofac Surg. 2018;29(1):116-123.

39. Katagiri W, Watanabe J, Toyama N, Osugi $\mathrm{M}$, Sakaguchi K, Hibi $\mathrm{H}$. Clinical study of bone regeneration by conditioned medium from mesenchymal stem cells after 
maxillary sinus floor elevation. Implant Dent. 2017;26(4):607-12.

40. Katagiri W, Osugi M, Kinoshita K, Hibi H. Conditioned medium from mesenchymal stem cells enhances early bone regeneration after maxillary sinus floor elevation in rabbits. Implant Dent. 2015; 24(6):657-663.

41. Osugi M, Katagiri W, Yoshimi R, Inukai T, Hibi $\mathrm{H}$, Ueda $\mathrm{M}$. Conditioned media from mesenchymal stem cells enhanced bone regeneration in rat calvarial bone defects. Tissue Eng Part A. 2012;18:14779-1489.

42. Xing J, Hou $T$, Jin $H$, Luo $F$, Chang $Z$, $\mathrm{Li} Z$, Xie Zh, Xu J. Inflammatory microenvironment changes the secretory profile of mesenchymal stem cells to recruit mesenchymal stem cells. Cell Physio Biochem. 2014;33:905-919

43. Singer NG, Caplan Al. Mesenchymal stem cells: Mechanisms of inflammation. Annu Rev Pathol. 2011;6:457-78.

44. Zhou Y, Fan W, Prasadam I, Crawford R, Xiao $Y$. Implantation of osteogenic differentiated donor mesenchymal stem cells causes recruitment of host cells. J Tissue Eng Regen Med; 2012.

DOI: 10.1002/term.1619

45. Zhou Y, Fan W, Prasadam I, Crawford R, Xiao $Y$. Implantation of osteogenic differentiated donor mesenchymal stem cells causes recruitment of host cells. J Tissue Eng Regen Med; 2012.

DOI: 10.1002/term.1619

46. Barba $\mathrm{M}$, Cicione $\mathrm{C}$, Bernardini C, Michetti F, Lattanzi W. Adipose-derived mesenchymal cells for bone regeneration: State of the art. BioMed Research International. 2013;9:1-11.

47. Alwattar BJ, Schwarzkopf R, Kirsch $T$. Stem cells in orthopaedics and fracture healing. Bulletin of the NYU Hospital for Joint Diseases. 2011;69(1):6-10.

48. Katagiri W, Osugi M, Kawai $T$, Hibi $H$. First in human study and clinical case reports of the alveolar bone regeneration with the secretome from human mesenchymal stem cells. Head Face Med. 2016;12:5.

49. Bertolai R, Catelani C, Aversa A, Rossi A, Giannini D, Bani D. Bone graft and mesenchymal stem cells: Clinical observations and histological analysis. Clin cases miner bone metab. 2015;12(2): 183-7.

50. Smiller D, Soltan M, Lee JW. A histomorphometric analysis of bone grafts augmented with adult stem cells. Implant Dent. 2007;16(1):42-53.

(C) 2019 Dilogo and Fiolin; This is an Open Access article distributed under the terms of the Creative Commons Attribution License (http://creativecommons.org/licenses/by/4.0), which permits unrestricted use, distribution, and reproduction in any medium, provided the original work is properly cited.

Peer-review history:

The peer review history for this paper can be accessed here: http://www.sdiarticle3.com/review-history/41691 